\title{
Valorization of Peel Wastes of Purple Turnip (Brassica rapa L.): Extraction of Polyphenolics Through Ultrasonic-Assisted Extraction and Investigation of Changes in Total Phenolic Content, Total Monomeric Anthocyanin Content and Total Antioxidant Capacity During in vitro Gastro-Intestinal Digestion
}

\author{
Aysun Yucetepe* \\ *Aksaray University, Faculty of Engineering, Departmant of Food Engineering, Aksaray, Turkey, (ORCID: 0000-0002-3800-4774), aysunyucetepe@aksaray.edu.tr,
}

(First received 9 June 2021 and in final form 16 August 2021)

(DOI: $10.31590 /$ ejosat.949244)

ATIF/REFERENCE: Yucetepe, A. (2021). Valorization of peel wastes of purple turnip (Brassica rapa L.): Extraction of phenolics through ultrasonic-assisted extraction and investigation of changes in total phenolic content, total monomeric anthocyanin content and total antioxidant capacity during in vitro gastro-intestinal digestion. European Journal of Science and Technology, (27), 152-157.

\begin{abstract}
Fruits and vegetables include high levels of bioactive compounds with health-promoting effects. Especially, peels, which are one of the generaly inedible fractions of fruit or vegetable, have higher amount of polyphenolic compounds than their pulps or seeds, since they accumulate in their peels. Purple turnip (Brassica rapa L.) is one of the important members of Brassicaceae family due to its nutritional composition. In this context, the aim of the study was to reveal the potency of peels from purple turnip as a natural antioxidant ingredient To reach this aim, the spectrophotometric assays including the Folin-Ciocalteu method for total phenolic content (TPC), the $\mathrm{pH}$ differential method for total monomeric anthocyanin content (TMAC) and CUPRAC and DPPH methods for total antioxidant capacity (TAC) before and after in vitro gastro-intestinal digestion were carried out. According to results of the study, TPC and TMAC of the polyphenolic axtract obtained by ultrasound-assisted extraction were 169.29 $\pm 6.89 \mathrm{mg}$ GAE/g dw and 159.53 $\pm 10.82 \mathrm{mg}$ CGE/L, respectively. The TAC of the extracts was $44.19 \pm 0.10 \mathrm{mg}$ TE/g dw in CUPRAC assay and $38.52 \pm 0.06 \mathrm{mg}$ TE/g dw in DPPH assay. The bioaccessibilities of total phenolics and anthocyanins from extracts after in vitro digestion process were approximately $17 \%$ and $6 \%$ and the antioxidant capacity of the bioaccessible extract fraction was approximately 28\% (CUPRAC) and 0\% (DPPH).
\end{abstract}

Keywords: Anthocyanins, antioxidant capacity, bioaccessibility, phenolics, purple turnip.

\section{Mor Şalgam (Brassica rapa L.) Kabuk Atıklarının Değerlendirilmesi: Ultrasonik Destekli Ekstraksiyon ile Polifenoliklerin Ekstraksiyonu ve in vitro Mide-Bağırsak Sindirim Sırasında Toplam Fenolik Madde, Toplam Monomerik Antosiyanin Miktarı ve Toplam Antioksidan Kapasitedeki Değişimin Araştırılması}

Öz

Meyve-sebzeler sağlık üzerinde olumlu etkileri olan yüksek düzeyde biyoaktif bileşenler içermektedir. Özellikle meyve-sebzelerin yenilmeyen kısımlarından olan kabuklar, polifenolik bileşiklerin burada birikmesinden dolayı, iç veya çekirdeklerine göre daha yüksek oranda polifenolik bileşikler içermektedir. Mor şalgam (Brassica rapa L.), besinsel içeriğinden dolayı Brassicaceae ailesinin önemli üyelerinden biridir. Bu bağlamda, bu çalışmanın amacını, mor şalgam sebzesinden kabukların in vitro mide-bağırsak sindirim öncesi ve sonrasında, spektrofotometrik yöntemlerden olan toplam fenolik madde için Folin-Ciocalteu metodu, toplam monomerik antosiyanin içerik için pH diferansiyel metot ve toplam antioksidan kapasite için CUPRAC ve DPPH yöntemlerini kullanarak, doğal bir antioksidan kaynağı olarak potansiyelinin araştırılması oluşturmaktadır. Çalışmanın sonuçlarına göre, ultrases destekli ekstraksyon ile elde edilen

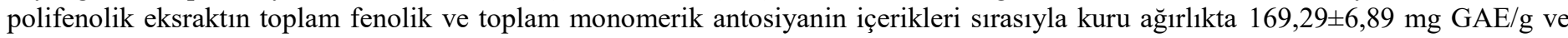
$159,53 \pm 10,82 \mathrm{mg}$ CGE/L olarak bulunmuştur. Ekstraktların toplam antioksidan kapasitesi ise CUPRAC yöntemi ile kuru ağırlıkta

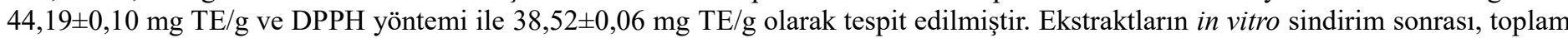
fenolik ve antosiyaninlerin biyoerişilebilirliği yaklaşık olarak sırasıyla $\% 17$ ve $\% 7$ olarak hesaplanmıştır. Ayrıca biyoerişilebilir ekstrakt fraksiyonunun antioksidan kapasitesi CUPRAC yöntemi ile yaklaşık \%28 ve DPPH yöntemi ile yaklaşık \%0 olarak bulunmuştur.

Anahtar Kelimeler: Antioksidan kapasitesi, antosiyaninler, biyoerişilebilirlik, fenolikler, mor şalgam. 


\section{Introduction}

Extraction is one of the most important process in the field of food science, since it helps to obtain bioactive molecules to produce functional ingredients. In this context, the main purpose of the extraction process is to maximize the yield of target molecules from food matrice without/with minimal effect on their bioactive or functional properties. Conventional extraction methods with low extraction efficiency such as solid-liquid extraction, maceration and heat reflux possess many disadvantages including intensive usage of organic solvents, and energy, longer time and heating. In addition to these reasons, presence of solvent residues with toxic effects in extracted target compounds cause to develop environment-friendly extraction methods such as ultrasound-assisted extraction, supercritical fluids or microwaves assisted extraction. Moreover, new extraction techniques have been needed to maximize process efficiency (Kulkarni \& Rathod, 2014; Tiwari, 2015; Ojha et al., 2020).

The use of ultrasonic waves for the extraction of bioactive compounds from various foods such as fruit, vegetable, grain and cereal has been extensively reported in recent years, mainly since it is an economical, enviroment-friendly and efficient alternative to conventional extraction techniques (Albero et al., 2019). Ultrasonic waves, used in a range of $20-1000 \mathrm{kHz}$ in ultrasoundassisted extraction (UAE), are spread through target matrices via compression and rarefaction. The scattering of ultrasonic waves into liquid extraction media leads to a negative pressure in the media. Small voids or bubbles forms when a soundwave pressure of higher intensities are dispersed through a liquid media. When these voids or bubbles are filled with a gas or water vapour, growth and shrinkage of bubbles occurs until they collapse resulting in cavitation (Ojha et al., 2020). Therefore, ultrasound technology can be used to increase extraction efficiency by disrupting cell tissues in extraction applications of value substances from plant, algae or animal sources (Bakht et al., 2019).

In recent years, many studies have been performed on the ultrasonic treatment of plant materials in order to improve the extraction efficiency and preserve the stability of active compounds such as phenolics, plant pigments since they possess a basic role in determination of plant's bioactive properties such as antioxidant, antihypertensive, antidiabetic, etc. (Jovanović et al., 2017; Đurović et al., 2018; Siewe, Kudre et al., 2020; Sukor et al., 2020; Torić et al., 2020; Yücetepe et al., 2020). In this context, the stability of phenolic extracts from plants has a big importance in terms of preserving their biofunctional characters.

Anthocyanins, a sub-group of polyphenols, are natural pigments. There are six main anthocyanin compounds named as malvidin, delphinidin, pelargonidin, cyanidin, petunidin, and peonidin derivatives. The factors effected on this classification of anthocyanins are the numbers of sugars, hydroxyl groups and aliphatic or aromatic acid groups and their position in the chemical structure (Park et al., 2016). Anthocyanins with healthpromoting effects are responsible for brilliant colours such as red, purple, and orange of most of fruit and vegetable such as turnips, radishes, grapes, berries and red cabbage. On the other hand, they are highly sensitive against environmental conditions including temperature, light, oxygen, etc. (He \& Giusti, 2011; Azima et al., 2017; Mansour et al., 2020).
Turnip (Brassica rapa L.), which belongs Brassicaceae family, is a leaf and root vegetable rich in dietary phenolics and other important phytochemicals such as anthocyanins, carotenoids, glucosinolates, vitamin C, dietary fiber. Turnip vegetables have several varieties with purple pigments characterized as anthocyanins with beneficial health effects. In various studies conducted on pharmacological properties of turnip, it has been proved its antitumor, antihypertensive, antidiabetic, antioxidant, anti-inflammatory, hepatoprotective, and nephroprotective activities (Khoo et al., 2017; Zhuang et al., 2019; Ma et al., 2021).

In previous studies, chemical composition and antioxidant activity of turnip vegetable were investigated by the other groups (Sultana et al., 2008; Noreen et al., 2010; Saeed et al., 2012; Deng et al., 2013; Bhandari et al., 2015; Djenidi et al., 2020). So far, to the best of our knowledge, no research has been conducted on bioaccessibility of polyphenolic extracts from peels of purple turnip (PEPPT) after in vitro digestion. Therefore, the aims of the present study were to determine changes in total phenolic content (TPC) and total monomeric anthocyanin contents (TMAC), and total antioxidant capacity (TAC) during in vitro digestion.

\section{Material and Method}

\subsection{Materials}

\subsubsection{Plant Material}

Purple turnips were supplied from a local market of Aksaray province in Turkey. Peels were removed and cut into small pieces using a knife, after the samples were washed with tap water. Afterwards, the peels were lyophilized and were stored at $-80{ }^{\circ} \mathrm{C}$ immedialtely until analysis.

\subsubsection{Chemicals}

Folin Ciocalteu's phenol reagent was purchased from Merck (Merck, Darmstadt, Germany). Hydrochloric acid, sodium hydroxide, ethanol, methanol, formic acid, gallic acid, potassium chloride, sodium bicarbonate, sodium cloride, sodium carbonate, copper (II) chloride solution, $7.5 \mathrm{mM}$ neocuproine solution, ammonium acetate buffer, 1,1-diphenyl-2-picrylhydrazyl, ( \pm )-6hydroxy-2,5,7,8-tetramethylchromane-2-carboxylicacid(Trolox), copper (II) chloride solution, ammonium acetate buffer, potassium dihydrogen phosphate, disodium phosphate, potassium chloride, bile salt, $\alpha$-amylase, pepsin, pancreatin were purchased from Sigma-Aldrich (Sigma-Aldrich Chemie, St. Louis, Missouri, USA). All solvents and chemicals used were of analytical grade.

\subsection{Ultrasonic-Assisted Extraction of Peel Phenolics}

The method of Gras et al. (2015) was performed for extraction of polyphenolics from turnip peel with some modifications. An aliquot of $0.5 \mathrm{~g}$ of lyophilized samples was mixed with $15 \mathrm{~mL}$ methanolic solution (MetOH: $\mathrm{H}_{2} \mathrm{O}: \mathrm{CH}_{2} \mathrm{O}_{2}$, $80: 19: 1, \mathrm{v} / \mathrm{v})$. In the present study, $80 \%$ aqueous methanol was used as solvent in extraction process since it was reported by Sarwari et al. (2019) that the extraction of plant phenolics is the highest level at this concentration. The UAE was carried out under at $65 \%$ amplitude for $15 \mathrm{~min}$ in a ultrasonic bath (Kudos LHC ultrasonic cleaners, Kudos, China). During sonication, the samples were cooled in an ice bath to avoid sample heating. After ultrasonic treatment, the extraction process was carried out at 25 ${ }^{\circ} \mathrm{C}$ for $1 \mathrm{~h}$ in a shaking water bath (N-Biotek-303, Biotek Co., Ltd. 
Korea). Then, the samples were centrifugated at 4,100 rpm and 4 ${ }^{\circ} \mathrm{C}$ for $15 \mathrm{~min}$. The collected supernatants were stored at $-20{ }^{\circ} \mathrm{C}$ in the dark until analysis. All the experimental results obtained in this work were expressed by the dry weight (dw) of the sample.

\subsection{In vitro Gastro-Intestinal Digestion}

The bioaccessibility (\%) of the bioaccessible fractions under in vitro gastro-intestinal digestion was determined according to the method of Świeca et al. (2013). Firstly, the samples were mixed with $15 \mathrm{~mL}$ of a saliva solution, which was prepared with $0.19 \mathrm{~g} \mathrm{KH}_{2} \mathrm{PO}_{4}, 2.38 \mathrm{~g} \mathrm{Na}_{2} \mathrm{HPO}_{4}$, and $8 \mathrm{~g} \mathrm{NaCl}$ in $1 \mathrm{~L}$ of distilled water, for $10 \mathrm{~min} 37^{\circ} \mathrm{C}$ in the shaking water bath. Afterwards, the $\mathrm{pH}$ of the samples was adjused to 1.2 and $15 \mathrm{~mL}$ of gastric solution prepared with the pepsin enzyme in $0.03 \mathrm{M} \mathrm{NaCl}$ was added to the mixture and incubated in the shaking water bath for $60 \mathrm{~min}$ at $37{ }^{\circ} \mathrm{C}$ for the gastric digestion. Then, the $\mathrm{pH}$ of the samples was adjusted to 6.0 and they were incubated with pancreatin and $15 \mathrm{~mL}$ of bile extract in the shaking water bath for $120 \mathrm{~min}$ at $37^{\circ} \mathrm{C}$ in the dark. The supernatants were collected after centrifugation process at $6,000 \mathrm{rpm}$ for $15 \mathrm{~min}$ and stored immediatelly $-80{ }^{\circ} \mathrm{C}$ until analysis. The formula of bioaccessibility (\%) was shown below:

$$
\text { Bioaccessibility }(\%)=\frac{\mathrm{A}}{\mathrm{B}} \times 100
$$

Where $\mathrm{A}$ is TPC, TMAC and TAC determined after in vitro gastro-intestinal digestion; B is TPC, TMAC and TAC determined before in vitro gastro-intestinal digestion.

\subsection{Determination of Total Phenolic Content}

Folin-Ciocalteu method was performed to determine the TPC of the extracts (Toor \& Savage, 2006). Briefly, $200 \mu \mathrm{l}$ of the extracts, $1.5 \mathrm{~mL}$ from 10 fold diluted Folin-Ciocalteu reagent and $1.2 \mathrm{~mL}$ of aqueous $7.5 \% \mathrm{Na}_{2} \mathrm{CO}_{3}$ were mixed and this mixture was stood at room temperature in the dark for $90 \mathrm{~min}$. The absorbance values of the samples were measured at $765 \mathrm{~nm}$ using an UV spectrophotometer (Scilogex Sci-UV1000 Spectrophotometer, Scilogex, USA). The results are given as milligrams per gram of gallic acid equivalents ( $\mathrm{mg} \mathrm{GAE} / \mathrm{g} \mathrm{dw}$ ).

\subsection{Total Monomeric Anthocyanin Content}

Total monomeric anthocyanin content of PEPPT was determined using the $\mathrm{pH}$ differential method (Hanlon \& Barnes, 2011). The absorbance of samples was measured at $520 \mathrm{~nm}$ and $700 \mathrm{~nm}$ at $0.025 \mathrm{M} \mathrm{KCl}(\mathrm{pH} 1.0)$ and $0.4 \mathrm{M} \mathrm{CH}_{3} \mathrm{CO}_{2} \mathrm{Na}(\mathrm{pH} 4.5)$ buffer solutions using the UV spectrophotometer and calculated by the equation given below:

$$
\operatorname{TMAC}\left(\frac{\mathrm{mg}}{\mathrm{kg}}\right)=\frac{\mathrm{A} \times \mathrm{MW} \times \mathrm{DF} \times 10^{3}}{\varepsilon \times \mathrm{L}}
$$

Where $\mathrm{A}=(\mathrm{A} 520-\mathrm{A} 700)_{\mathrm{pH}} 1.0-(\mathrm{A} 520-\mathrm{A} 700)_{\mathrm{pH}} 4.5, \mathrm{MW}$ : The molecular weight of cyanidin-3-O-glucoside $(449.2 \mathrm{~g} / \mathrm{mol})$, DF: The dilution factor, $\varepsilon$ : The molar extinction coefficient of cyanidin-3-O-glucoside $(26,900 \mathrm{~L} / \mathrm{cm} . \mathrm{mol})$ and L: The path length $(1 \mathrm{~cm})$. Total anthocyanin concentration was calculated as cyanidin-3-glucoside equivalent.

\subsection{Evaluation of Total Antioxidant Capacity}

\subsubsection{The Cupric Reducing Antioxidant Capacity (CUPRAC) Method}

The CUPRAC assay was performed to determine antioxidant capacity of the samples (Apak et al., 2004). Briefly, $100 \mu \mathrm{L}$ of sample extract was mixed with $1 \mathrm{~mL}$ each of $0.1 \mathrm{mM}$ copper (II) chloride solution, $7.5 \mathrm{mM}$ neocuproine solution, ammonium acetate buffer solution ( $\mathrm{pH} 7.0$ ), and distilled water. The mixture was incubated at room temperature for $30 \mathrm{~min}$. Then, the absorbance of the mixture was measured at $450 \mathrm{~nm}$ using the UV spectrophotometer. Trolox was used as a reference compound and results were expressed as mg Trolox equivalents ( $\mathrm{mg} \mathrm{TE} / \mathrm{g} \mathrm{dw}$ ).

\subsubsection{The 1,1-Diphenyl-2-picrylhydrazyl (DPPH) Free Radical Scavenging Method}

The DPPH assay was carried out according to the method of Kumaran and Karunakaran (2006). Briefly, $100 \mu \mathrm{L}$ of sample extract was mixed with $2 \mathrm{~mL}$ of $0.1 \mathrm{mM}$ DPPH in methanol. The mixture was left to stand for $30 \mathrm{~min}$ in dark at room temperature. Then, the absorbance of the mixture was read at $517 \mathrm{~nm}$ using the UV spectrophotometer. The results were expressed as mg TE/g dw.

\subsection{Statistical Analysis}

Experimental data was showed as mean \pm standard deviation (SD). The data was analysed using a statistical package (Minitab, Version 17, Minitab Inc., State College, Pennsylvania, USA). The differences between mean values were compared using Tukey test. Differences at $\mathrm{p} \leq 0.05$ were considered to be significant.

\section{Results and Discussion}

\subsection{Changes in TPC and TMAC of The Extracts During in vitro Digestion}

To detect the effects of in vitro digestion on the TPC, TMAC and TAC values of the undigested and digested PEPPT were determined and showed in Table 1. According to the results of the analysis, TPC and TMAC were $169.29 \pm 6.89 \mathrm{mg} \mathrm{GAE} / \mathrm{g} \mathrm{dw}$ and $159.53 \pm 10.82 \mathrm{mg} \mathrm{CGE} / \mathrm{L}$ for the undigested samples, respectively. The TMAC of the extracts decreased both gastric and intestinal digestion phases $(p<0.05)$, while TPC of the sample decreased only gastric stage $(\mathrm{p}<0.05)$ during in vitro digestion. The decrease of TPC and TMAC may arise from the partial degradation of some phenolic compounds during in vitro digestion (Ma et al., 2020). So far, there have not been enough scientific information in the literature on the in vitro digestion of purple turnip phytochemicals. Therefore comparisons were carried out using the data from other vegetables/plants, which belong to the Brassicaceae family. According to the study of Park et al. (2016), three radish cultivars were compared in terms of anthocyanin and total phenolic contents. Among them, the cultivar ManTang Hong contained the highest total anthocyanins in dry weight $(1.89 \mathrm{mg} / \mathrm{g})$. In another study, TMACs for broccoli, kale, mustard, radish from the Brassicaceae family were determined as $1.39,5.57,12.66,36.40 \mathrm{mg} / 100 \mathrm{~g} \mathrm{dw}$, respectively. Additionally, the authors reported that TMAC was not detected in any samples after in vitro digestion process (de la Fuente et al., 2019). On the other hand, Sarwari et al. (2019) investigated TPC (59.41 mg GAE/g dw) of peel extracts from turnip. According to Goyeneche et al. (2015), TPC of methanolic extracts from leaves of red radish was $6.95 \mathrm{mg} \mathrm{GAE} / \mathrm{g} \mathrm{dw}$. Similarly, in Pajak et al. (2014)'s study, TPC of methanolic extracts of radish sprouts was found as approximately $12 \mathrm{mg} \mathrm{GAE} / \mathrm{g} \mathrm{dw}$. In these studies, ultrasound treatment was performed during extraction and this may be a reason of lower phenolic content in extracts than our 
findings, because ultrasonic waves may cause an increase in the extraction of valuable compounds from plant tissues by disrupting cell during extraction (Bakht et al., 2019). Similarly, Golmohamadi (2013) determined the increase in total phenolics at $986 \mathrm{kHz}$ during sonication and they explained that ultrasonic waves and increase in temperature can facilitate migration of phenolics from the red raspberry fruit to extraction media.

Total phenolic content and in vitro antioxidant activity of several vegetables from Brassicaceae family were investigated by Xiao et al. (2019). These authors determined TPCs ranged from 26.48 and $15.97 \mathrm{mg} \mathrm{GAE} / \mathrm{g}$ fresh weight for red radish and turnip, respectively. Similar to their study, de la Fuente et al. (2019) reported that TPCs of broccoli, kale, mustard and radish microgreens were 20.37, 24.16, 18.90 and $21.11 \mathrm{mg} \mathrm{GAE} / \mathrm{g} \mathrm{dw}$, respectively. Moreover, TPC was determined as 27.99, 34.61, 30.27, $47.36 \mathrm{mg} \mathrm{GAE} / \mathrm{g}$ dw by Tomas et al. (2021) for kale, red cabbage, kohlbari and purple radish, respectively. However, TPC of PEPPT in the present study is not comparable with these values reported in previous works, because TPC of all parts of the vegetables such as peel and pulp was investigated in these studies. However, TPC of the polyphenolic extract of peels from purple turnip was determined in our study. Therefore, the TPC was found in higher amount than those found in these studies mentioned above, since phenolic and anthocyanin accumulate in the peels of fruits and vegetables.

\subsection{Changes in TAC of The Extracts During in vitro Digestion}

Antioxidant activity of the samples before in vitro digestion was detected as $44.19 \pm 0.10 \mathrm{mg} \mathrm{TE} / \mathrm{g}$ by CUPRAC assay and $38.52 \pm 0.06 \mathrm{mg}$ TE/g by DPPH assay. Similarly, in the study of Tomas et al., (2021) TAC of kale, red cabbage, kohlbari and purple radish from Brassicaceae family was found as 44.1752 .13 , 44.48, $66.94 \mathrm{mg}$ TE/g dw by CUPRAC assay, respectively. The TAC by DPPH method ranged from 17.24 to $22.73 \mathrm{mg} \mathrm{TE} / \mathrm{g} \mathrm{dw}$ for same plants (Tomas et al, 2021). In a study on several vegetables from Brassicaceae, TAC values obtained from DPPH method were 15.31 and $9.42 \mathrm{mg} \mathrm{TE} / \mathrm{g} \mathrm{dw}$ for red cabbage and radish, respectively (Xiao et al., 2019). It is generally known that plant containing higher level of TPC shows superior antioxidant activities (Chel-Guerrero et al. 2018).

In our study, the CUPRAC values of the extracts decreased after only in vitro gastric digestion $(\mathrm{p}<0.05)$ while the DPPH values decreased after both in vitro gastric and intestinal digestions $(\mathrm{p}<0.05)$. Similarly, DPPH values decreased after in vitro digestion of edible flowers and some vegetables in Puangkam et al. (2017) and Chen et al. (2015)'s studies, respectively. As a reason of this decrease, it can be hypothesized that biological reactivity of antioxidant compounds can alter during in vitro digestion and they may less reactive at $\mathrm{pH} \sim 7.4$ in intestinal digestion. Moreover, similar results were reported for some fruits and vegetables in the other studies, as well (Vinholes et al., 2018; Goulas and Hadjisolomou, 2019; Tomas et al., 2021). The decrease in TAC was observed with both methods after in vitro gastro-intestinal digestion, may be related to the reduction in bioactive antioxidant compounds such as total phenolics and total anthocyanins (de la Fuente et al. (2019). The presence of bile salts and complexity of the food matrix and the changes in $\mathrm{pH}$ in gastric and intestine fluids could be responsible to decrease of antioxidant activity of polyphenols (Tagliazucchi et al., 2010). In contrast to the present study, the study of Chandrasekara and Shahidi (2012) showed an increase in TPC and TAC of grain samples after in vitro gastro-intestinal digestion, because the low $\mathrm{pH}$ (2.0) that could improve the release of phenolics by breaking their binding with food matrix (Chandrasekara and Shahidi, 2012). These differences among the previous studies could be attributed to the different samples used and the compounds formed after in vitro digestion, which can react with substrates and free radicals depending on each antioxidant assay and the food matrix.

\subsection{The Bioaccesibility (\%) of TPC, TMAC and TAC During in vitro Digestion}

The bioaccesibility of TPC and TMAC was found to be $17.03 \pm 0.07 \%$ and $6.16 \pm 0.52 \%$, after in vitro gastro-intestinal digestion, respectively ( $\mathrm{p}<0.05$, Figure 1$)$. Moreover, TAC of the bioaccessible fraction was determined to be $27.57 \pm 0.48 \%$ in CUPRAC assay and to be $0.51 \pm 0.39 \%$ in DPPH assay. The bioaccessibility of TPC, TMAC and TAC by DPPH assay was significantly lower $(\mathrm{p}<0.05)$ in both gastric and intestinal phases. Additionaly, the bioaccessibility ( $\%$ ) of total antioxidant capacity was significantly lower $(p<0.05)$ in gastric phase than intestine phase in terms of CUPRAC assay. On the other hand, the bioaccessibility (\%) of total antioxidant capacity was significantly lower $(p<0.05)$ in both gastric and intestinal phases in terms of DPPH assay. Between the CUPRAC and DPPH assays, the highest TAC values were monitored by CUPRAC assay after in vitro digestion. According to Apak et al. (2013), the reason of obtaining higher bioaccesibility values by CUPRAC assay than DPPH assay after in vitro digestion process could arise from the selectivity and stability of CUPRAC assay (Apak et al., 2013). In addition, in vitro antioxidant tests are incapable of revealing of all antioxidant potentials available in the sample analyzed could be the reason of the discrepancy between CUPRAC and DPPH assays (Tomas et al., 2021).

Similarly, in a study carried out by de la Fuente et al., the TPC, TMAC and TAC of the bioaccessible fractions of Brassicaceae plants including broccoli, kale, mustard and radish decreased after in vitro digestion (de la Fuente et al., 2019). Moreover, Yucetepe et al. (2021) reported decreases in TPC (approximately 5\%) and TAC (6\% in CUPRAC and $36 \%$ in $\mathrm{DPPH})$ of the extracts from black radish peel $(\mathrm{p}<0.05)$ after in vitro digestion. These decreases in both in vitro gastric and intestinal digestions may be related to the $\mathrm{pH}$ and the presence of other compounds in food and enzymes, causing irreversible changes in the chemistry and physical state of polyphenols (Yucetepe, et al., 2021, Tomas et al., 2021). 
Table 1. Total phenolic content, total monomeric anthocyanin content, total antioxidant capacities of the digested and undigested samples.

\begin{tabular}{|l|c|c|c|}
\hline Analysis & Initial & Gastric phase & Intestinal phase \\
\hline TPC (mg GAE/g dw) & $169.29 \pm 6.89^{\mathrm{a}}$ & $39.47 \pm 2.71^{\mathrm{b}}$ & $28.83 \pm 0.17^{\mathrm{b}}$ \\
\hline TMAC (mg CGE/L) & $159.53 \pm 10.82^{\mathrm{a}}$ & $15.82 \pm 0.11^{\mathrm{b}}$ & $9.77 \pm 0.17^{\mathrm{c}}$ \\
\hline CUPRAC (mg TE/g dw) & $44.19 \pm 0.10^{\mathrm{a}}$ & $12.64 \pm 0.08^{\mathrm{b}}$ & $12.25 \pm 0.21^{\mathrm{b}}$ \\
\hline DPPH (mg TE/g dw) & $38.52 \pm 0.06^{\mathrm{a}}$ & $26.67 \pm 0.60^{\mathrm{b}}$ & $0.51 \pm 0.39^{\mathrm{c}}$ \\
\hline
\end{tabular}

All the values were expresed as means \pm standard deviation. The mean is an average of three samples $(n=3)$ obtained from the triplicated experiments. Different superscripts letters within the same line indicate significant difference ( $p<0.05$, Tukey).

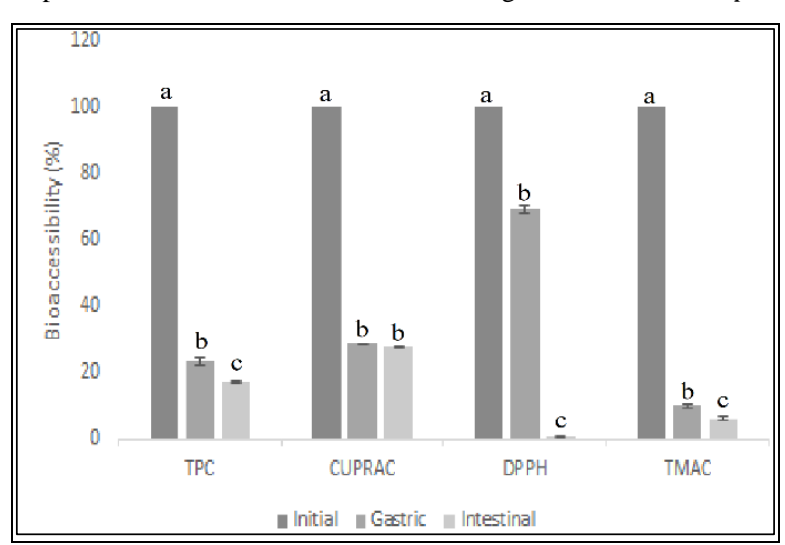

Figure 1. The bioaccessibility (\%) of polyphenolic extracts from purple turnip peel waste, in terms of total phenolic content (TPC), total monomeric content (TMAC) and TAC (CUPRAC and DPPH methods) in post-gastric and post-intestine phases.

\section{Conclusions and Recommendations}

In this work, the potency of peel extracts from the purple turnip was revealed as a natural antioxidant with healthpromoting effects arising from bioactive compounds such as phenolics and anthocyanins. The bioaccessibility of the phenolic and athocyanin fractions and their total antioxidant capacity after in vitro digestion are provided for the first time. According to our results, the purple turnip exhibited higher amount of total phenolics and total monomeric anthocyanins than other Brassicaceae vegetables. On the contrary, it had similar antioxidant capacity compared to the Brassicaceae vegetables. In fact, although the predicted decrease in bioactive compounds such as phenolics and anthocyanins after in vitro digestion process, total antioxidant capacity (by CUPRAC assay) of these fractions could be protected at the level of approximately $28 \%$. However, more studies are needed to determine the total antioxidant capacity in the gastrointestinal tract by using other assays such as ABTS, ORAC, FRAP. Therefore, in further studies, increasing the bioaccessibility of the antioxidant compounds after in vitro digestion through new strategies such as encapsulation and determining their potential bioactivity in animal studies should be addressed.

\section{References}

Albero, B., Tadeo, J. L., \& Pérez, R. A. (2019). Ultrasound-assisted extraction of organic contaminants. TrAC Trends in Analytical Chemistry, 118, 739-750.

Ali, H., Houghton, P., \& Soumyanath, A. (2006). $\alpha$-Amylase inhibitory activity of some Malaysian plants used to treat diabetes; with particular reference to Phyllanthus amarus. Journal of ethnopharmacology, 107(3), 449-455.

Apak, R., Güçlü, K., Özyürek, M., \& Karademir, S. E. (2004). Novel total antioxidant capacity index for dietary polyphenols and vitamins $\mathrm{C}$ and $\mathrm{E}$, using their cupric ion reducing capability in the presence of neocuproine: CUPRAC method. Journal of Agricultural and Food Chemistry, 52(26), 7970-7981. Doi: 10.1021/jf048741x

Apak, R., Gorinstein, S., B"ohm, V., Schaich, K. M., "Ozyürek, M., \& Güçlü, K. (2013). Methods of measurement and evaluation of natural antioxidant capacity/activity (IUPAC technical report). Pure and Applied Chemistry, 85(5), 957-998.

Azam, A., Khan, I., Mahmood, A., \& Hameed, A. (2013). Yield, chemical composition and nutritional quality responses of carrot, radish and turnip to elevated atmospheric carbon dioxide. Journal of the Science of Food and Agriculture, 93(13), 32373244.

Azima, A. S., Noriham, A., \& Manshoor, N. (2017). Phenolics, antioxidants and color properties of aqueous pigmented plant extracts: Ardisia colorata var. elliptica, Clitoria ternatea, Garcinia mangostana and Syzygium cumini. Journal of Functional Foods, 38, 232-241.

Bakht, M. A., Geesi, M. H., Riadi, Y., Imran, M., Ali, M. I., Ahsan, M. J., \& Ajmal, N. (2019). Ultrasound-assisted extraction of some branded tea: Optimization based on polyphenol content, antioxidant potential and thermodynamic study. Saudi journal of biological sciences, 26(5), 1043-1052.

Banihani, S. A. (2017). Radish (Raphanus sativus) and diabetes. Nutrients, 9(9), 1014.

Barillari, J., Cervellati, R., Costa, S., Guerra, M. C., Speroni, E., Utan, A., \& Iori, R. (2006). Antioxidant and choleretic properties of Raphanus sativus L. sprout (Kaiware Daikon) extract. Journal of agricultural and food chemistry, 54(26), 9773-9778.

Chandrasekara, A., \& Shahidi, F. (2012). Bioaccessibility and antioxidant potential of millet grain phenolics as affected by simulated in vitro digestion and microbial fermentation. Journal of Functional Foods, 4(1), 226-237.

Chel-Guerrero, L. D., Sauri-Duch, E., Fragoso-Serrano, M. C., PérezFlores, L. J., Gómez-Olivares, J. L., Salinas-Arreortua, N., ... \& Mendoza-Espinoza, J. A. (2018). Phytochemical profile, toxicity, and pharmacological potential of peels from four species of tropical fruits. Journal of medicinal food, 21(7), 734743.

Chen, G. L., Chen, S. G., Xie, Y. Q., Chen, F., Zhao, Y. Y., Luo, C. X., \& Gao, Y. Q. (2015). Total phenolic, flavonoid and antioxidant activity of 23 edible flowers subjected to in vitro digestion. Journal of Functional Foods, 17, 243-259.

de la Fuente, B., L'opez-García, G., M’ãnez, V., Alegría, A., Barber'a, R., \& Cilla, A. (2019). Evaluation of the bioaccessibility of antioxidant bioactive compounds and minerals of four genotypes of Brassicaceae microgreens. Foods, $8(7), 250$.

Đurović, S., Nikolić, B., Luković, N., Jovanović, J., Stefanović, A., Šekuljica, N., . . . Knežević-Jugović, Z. (2018). The impact of high-power ultrasound and microwave on the phenolic acid profile and antioxidant activity of the extract from yellow soybean seeds. Industrial Crops and Products, 122, 223-231.

Golmohamadi, A., Möller, G., Powers, J., \& Nindo, C. (2013). Effect of ultrasound frequency on antioxidant activity, total phenolic and anthocyanin content of red raspberry puree. Ultrasonics sonochemistry, 20(5), 1316-1323.

Goulas, V., \& Hadjisolomou, A. (2019). Dynamic changes in targeted phenolic compounds and antioxidant potency of carob fruit 
(Ceratonia siliqua L.) products during in vitro digestion. LWT, 101, 269-275.

Goyeneche, R., Roura, S., Ponce, A., Vega-Gálvez, A., QuispeFuentes, I., Uribe, E., \& Di Scala, K. (2015). Chemical characterization and antioxidant capacity of red radish (Raphanus sativus L.) leaves and roots. Journal of Functional Foods, 16, 256-264.

Gras, C.C., Carle, R., Schweiggert, R.M. 2017. Determination of anthocyanins from black carrots by UHPLC-PDA after ultrasound-assisted extraction, Journal of Food Composition and Analysis, 44, 170-177.

Hanlon, P. R., \& Barnes, D. M. (2011). Phytochemical composition and biological activity of 8 varieties of radish (Raphanus sativus L.) sprouts and mature taproots. Journal of Food Science, 76(1), C185-C192.

Hanlon, P. R., Robbins, M. G., Hammon, L. D., \& Barnes, D. M. (2009). Aqueous extract from the vegetative portion of Spanish black radish (Raphanus sativus L. var. niger) induces detoxification enzyme expression in HepG2 cells. Journal of functional foods, 1(4), 356-365.

He, J., \& Giusti, M. M. (2011). High-purity isolation of anthocyanins mixtures from fruits and vegetables-A novel solid-phase extraction method using mixed mode cation-exchange chromatography. Journal of Chromatography A, 1218(44), 7914-7922.

Helrich, K. (1990). Official Methods of analysis of the Association of Official Analytical Chemisty.

Jiang, W., \& Zhou, X. (2019). Hydrolysis of radish anthocyanins to enhance the antioxidant and antiproliferative capacities. Food Chemistry, 294, 477-485.

Jovanović, A. A., Đorđević, V. B., Zdunić, G. M., Pljevljakušić, D. S., Šavikin, K. P., Gođevac, D. M., \& Bugarski, B. M. (2017). Optimization of the extraction process of polyphenols from Thymus serpyllum L. herb using maceration, heat-and ultrasound-assisted techniques. Separation and Purification Technology, 179, 369-380.

Kazeem, M., Adamson, J., \& Ogunwande, I. (2013). Modes of inhibition of $\alpha$-amylase and $\alpha$-glucosidase by aqueous extract of Morinda lucida Benth leaf. BioMed research international, 2013.

Kjeldahl, C. (1883). A new method for the determination of nitrogen in organic matter. Z Anal Chem, 22, 366.

Kulkarni, V. M., \& Rathod, V. K. (2014). Mapping of an ultrasonic bath for ultrasound assisted extraction of mangiferin from Mangifera indica leaves. Ultrasonics sonochemistry, 21(2), 606611.

Kumaran, A., \& Karunakaran, R. J. (2006). Anti-oxidant activity of polyphenols from Phyllanthus debilis Klein ex Willd. Journal of Natural remedies, 6(2), 141-146.

Ma, Y., Yang, Y., Gao, J., Feng, J., Shang, Y., \& Wei, Z. (2020). Phenolics and antioxidant activity of bamboo leaves soup as affected by in vitro digestion. Food and Chemical Toxicology, 135, 110941.

Mansour, M., Salah, M., \& Xu, X. (2020). Effect of microencapsulation using soy protein isolate and gum arabic as wall material on red raspberry anthocyanin stability, characterization, and simulated gastrointestinal conditions. Ultrasonics sonochemistry, 63, 104927.

Ojha, K. S., Aznar, R., O'Donnell, C., \& Tiwari, B. K. (2020). Ultrasound technology for the extraction of biologically active molecules from plant, animal and marine sources. TrAC Trends in Analytical Chemistry, 122, 115663.

Pająk, P., Socha, R., Gałkowska, D., Rożnowski, J., \& Fortuna, T. (2014). Phenolic profile and antioxidant activity in selected seeds and sprouts. Food Chemistry, 143, 300-306.

Park, C. H., Baskar, T. B., Park, S. Y., Kim, S. J., Valan Arasu, M., Al-Dhabi, N. A., ... \& Park, S. U. (2016). Metabolic profiling and antioxidant assay of metabolites from three radish cultivars (Raphanus sativus). Molecules, 21(2), 157.

Puangkam, K., Muanghorm, W., \& Konsue, N. (2017). Stability of bioactive compounds and antioxidant activity of Thai cruciferous vegetables during in vitro digestion. Current Research in Nutrition and Food Science Journal, 5(2), 100-108.

Salah-Abbès, J. B., Abbès, S., Houas, Z., Abdel-Wahhab, M. A., \& Oueslati, R. (2008). Zearalenone induces immunotoxicity in mice: possible protective effects of radish extract (Raphanus sativus). Journal of Pharmacy and Pharmacology, 60(6), 761770 .

Sarwari, G., Sultana, B., Sarfraz, R. A., \& Zia, M. A. (2019). Cytotoxicity, antioxidant and antimutagenic potential evaluation of peels of edible roots and tubers. International Food Research Journal, 26(6).

Siewe, F. B., Kudre, T. G., \& Narayan, B. (2020). Optimisation of ultrasound-assisted enzymatic extraction conditions of umami compounds from fish by-products using the combination of fractional factorial design and central composite design. Food Chemistry, 334, 127498.

Sukor, N., Jusoh, R., Kamarudin, N., Halim, N. A., Sulaiman, A., \& Abdullah, S. (2020). Synergistic effect of probe sonication and ionic liquid for extraction of phenolic acids from oak galls. Ultrasonics sonochemistry, 62, 104876.

Świeca, M., Gawlik-Dziki, U., Dziki, D., Baraniak, B., \& Czyż, J. (2013). The influence of protein-flavonoid interactions on protein digestibility in vitro and the antioxidant quality of breads enriched with onion skin. Food Chemistry, 141(1), 451-458.

Tagliazucchi, D., Verzelloni, E., Bertolini, D., \& Conte, A. (2010). In vitro bio-accessibility and antioxidant activity of grape polyphenols. Food Chemistry, 120(2), 599-606.

Tiwari, B. K. (2015). Ultrasound: A clean, green extraction technology. TrAC Trends in Analytical Chemistry, 71, 100-109.

Toor, R. K., \& Savage, G. P. (2006). Effect of semi-drying on the antioxidant components of tomatoes. Food Chemistry, 94(1), 9097.

Tomas, M., Zhang, L., Zengin, G., Rocchetti, G., Capanoglu, E., \& Lucini, L. (2021). Metabolomic insight into the profile, in vitro bioaccessibility and bioactive properties of polyphenols and glucosinolates from four Brassicaceae microgreens. Food Research International, 140, 110039.

Torić, J., Brozovic, A., Baus Lončar, M., Jakobušić Brala, C., Karković Marković, A., Benčić, Đ., \& Barbarić, M. (2020). Biological Activity of Phenolic Compounds in Extra Virgin Olive Oils through Their Phenolic Profile and Their Combination with Anticancer Drugs Observed in Human Cervical Carcinoma and Colon Adenocarcinoma Cells. Antioxidants, 9(5), 453.

Vinholes, J., Reis, S. F., Lemos, G., Barbieri, R. L., de Freitas, V., Franzon, R. C., \& Vizzotto, M. (2018). Effect of in vitro digestion on the functional properties of Psidium cattleianum Sabine (araçá), Butia odorata (Barb. Rodr.) Noblick (butiá) and Eugenia uniflora L.(pitanga) fruit extracts. Food \& function, 9(12), 6380-6390.

Xiao, Z., Rausch, S. R., Luo, Y., Sun, J., Yu, L., Wang, Q., ... \& Stommel, J. R. (2019). Microgreens of Brassicaceae: Genetic diversity of phytochemical concentrations and antioxidant capacity. $L W T, 101,731-737$.

Yücetepe, A., Altin, G., \& Özçelik, B. (2021). A novel antioxidant source: evaluation of in vitro bioaccessibility, antioxidant activity and polyphenol profile of phenolic extract from black radish peel wastes (Raphanus sativus L. var. niger) during simulated gastrointestinal digestion. International Journal of Food Science \& Technology, 56(3), 1376-1384. 